\title{
MINISTÉRIO PÚBLICO FEDERAL E A TUTELA AMBIENTAL: UM ESTUDO EMPÍRICO SOBRE A EFICÁCIA DA AÇÃO CIVIL PÚBLICA COMO INSTRUMENTO PROCESSUAL
}

\author{
FEDERAL PROSECUTORS AND ENVIRONMENTAL PROTECTION: AN EMPIRICAL STUDY ON THE \\ EFFICIENCY OF THE PUBLIC CIVIL ACTION AS A PROCEDURAL INSTRUMENT
}

José Glauton Gurgel Lins ${ }^{1}$

Gustavo Raposo Pereira Feitosa ${ }^{2}$

\begin{abstract}
Resumo: $O$ presente trabalho tem por finalidade analisar a atuação do Ministério Público Federal na tutela jurisdicional do meio ambiente por meio de ação civil pública. $\bigcirc$ trabalho resulta pesquisa empírica em que se investigaram todas as ações civis públicas ajuizadas pelo MPF em Fortaleza-Ceará envolvendo matéria ambiental no período de 2009 a 2013. Realizou-se ainda estudo de caráter bibliográfico, com a revisão da literatura científica de referência acerca do direito ao meio ambiente ecologicamente equilibrado, sua tutela, bem como acerca do papel do MP após 1988. Os dados coletados revelaram que a prestação jurisdicional nessa seara se apresenta pouco eficaz nas tutelas de urgência e uma duração desarrazoada do processo. Partindo dessa análise, demonstrouse a necessidade de um redirecionamento no paradigma de atuação do MP da vertente "demandista", na qual segue a reboque das iniciativas dos órgãos de fiscalização e transfere a decisão sobre questões ambientais para o Judiciário, para trilhar na direção de um modelo "resolutivo", construindo extrajudicialmente soluções para os conflitos por meio dos instrumentos que lhes são facultados, como o Termo de Ajuste de Conduta (TAC), bem como racionalizando e planejando seus procedimentos por meio de dados e pesquisas.
\end{abstract}

Palavras-chave: Ministério Público Federal; tutela ambiental; ação civil pública; pesquisa empírica no direito; eficácia processual.

Abstract: The purpose of this study is to analyze the performance of the Federal Prosecutor (MPF) in the judicial protection of the environment through public civil actions. The paper is the result of an empirical research that investigated all public civil actions filed by the MPF in Fortaleza-Ceará involving environmental issues in the period from 2009 to 2013. A bibliographic study was carried out with the review of the scientific reference literature on the right to an ecologically balanced environment, its protection, as well as the role of the prosecutors (MP) after 1988. The data collected revealed that the jurisdictional injunction in this area is not very effective in emergency safeguards and shows an unreasonable duration of the process. Based on this analysis, it was demonstrated the need for a change in the MP's "litigator" paradigm, that is deeply dependent of the initiatives of the governmental agencies and that transfers the decision on environmental issues to the Judiciary. It's needed a move in the direction of a "resolutive" model, constructing extrajudicial solutions to the conflicts through the instruments that are available to them, such as the Term of Conduct Adjustment (TAC), as well as rationalizing and planning their procedures through data and research.

Keywords: Federal Public Prosecutors; environmental protection; public civil action; empirical research in law; procedural effectiveness.

Recebido em 13 de agosto de 2019 Avaliado em 2 de dezembro de 2020 (AVALIADOR A) Avaliado em 19 de novembro de 2020 (AVALIADOR B) Aceito em 8 de abril de 2021

\footnotetext{
1 Mestre em Direito Constitucional pela Universidade de Fortaleza; Bacharel em Administração de Empresas pela Universidade Estadual do Ceará; Professor de Introdução à Ciência do Direito na Universidade de Fortaleza; https://orcid. org/0000-0001-6974-572X; gurgellins@gmail.com

2 Doutor em Ciências Sociais pela Universidade de Campinas; Mestre em Sociologia pela Universidade Federal do Ceará; Professor Titular do Programa de Pós-Graduação em Direito Constitucional da Universidade de Fortaleza; https://orcid. org/0000-0002-3766-0112; gfeitosa@unifor.br
} 


\section{Introdução}

A Constituição Federal de 1988 intitulou o Ministério Público (MP) de "instituição permanente, essencial à função jurisdicional do Estado, incumbindo-lhe a defesa da ordem jurídica, do regime democrático e dos interesses sociais e individuais indisponíveis." (BRASIL, 1988, art. 127). O novo paradigma constitucional redefiniu o escopo essencial da instituição, historicamente ligada à persecução penal e à defesa de interesses de incapazes e institutos, desvinculando-o das estruturas dos chamados "Poderes do Estado". Ademais, estabeleceu princípios institucionais, autonomia administrativo-financeira e garantias e vedações aos membros.

Por outro lado, os instrumentos jurídicos para a realização do Estado Social e da democracia substancial não mais se compatibilizam com os modelos clássicos utilizados para atender aos conflitos interindividuais, de cunho liberal-positivista. Assim, constitucionalizou-se a ação civil pública e o inquérito civil (previstos de antanho na Lei n $7.347 / 85$ - Lei da Ação Civil Pública LACP) na Seção relativa ao Ministério Público, em que pese não ser o único legitimado para o manejo de ações coletivas.

Dentre os inúmeros bens jurídicos albergados na Constituição, destaca-se no presente trabalho o meio ambiente ecologicamente equilibrado. A inspiração inovadora do art. 225 legou da Conferência de Estocolmo sobre Meio Ambiente Humano, em 1972, diversos princípios sobre a temática e agregou ao Estado um novo objetivo: o desenvolvimento sustentável. Isso equivale a dizer que a proteção do meio ambiente e da qualidade de vida (das presentes e futuras gerações) inserem-se como critérios de aferição para participação e tomada de decisões políticas.

Mesmo havendo previsão constitucional imputando ao Poder Público e à coletividade o dever de defender e preservar o equilíbrio ambiental merece destaque a menção expressa desse intento nas funções institucionais do MP (art. 129, III). Desse modo, no tocante ao desafio da concretização desse direito difuso, legitima-se primordialmente o Parquet não só pela sua vertente "demandista", ou seja, de buscar o provimento jurisdicional necessário; mas também por sua atuação "resolutiva", mediante a utilização de instrumentos extrajudiciais de construção de consenso e negociação, como o Termo de Ajustamento de Conduta (TAC).

A constitucionalização do meio ambiente como um direito fundamental, em bases principiológicas e axiológicas, e sua correlação intrínseca com a legitimidade do Ministério Público para seu resguardo, demanda dessa instituição uma atuação eficaz, mormente voltada à concretização dos princípios da precaução e da prevenção, ainda assim em concomitância ao sistema de responsabilização civil objetiva por danos praticados contra a higidez ambiental. Além disso, impende resistir aos interesses econômicos tendentes a converter em valores monetários os diversos bens ambientais e as investidas perante o Legislativo para mitigar a amplitude da esfera protetiva estabelecida pelo constituinte originário e suas garantias. 
A primeira parte do estudo ocorreu por meio de pesquisa bibliográfica na literatura científica de referência, com ênfase nas obras que investigam o direito ao meio ambiente ecologicamente equilibrado, o desenho institucional do Ministério Público na ordem constitucional de 1988 e sobre a tutela ambiental por meio da ação civil pública.

A segunda parte do estudo ocorreu por meio de uma pesquisa empírica sobre todas as ações civis públicas ajuizadas pelo Ministério Público Federal (MPF) no Estado do Ceará perante a Justiça Federal no período de 2009 a 2013. A investigação centrada nesse estado serviu de ponto de partida para uma reflexão mais ampla acerca do próprio modelo de atuação do MPF na tutela ambiental no cenário nacional.

No período analisado, foram identificadas 238 ações civis públicas cujo objeto versava sobre a proteção do meio ambiente, o que corresponde à totalidade de demandas ajuizadas. Para o estudo das ações elaborou-se um questionário digital que correspondia às variáveis necessária para o estudo. Com a leitura das peças do processo, complementado com a consulta aos sistemas de acompanhamento processual online, conseguiu-se montar um banco de dados detalhado sobre essas ações. Ao final, os dados receberam análise estatística com o auxílio de software SPSS.

Ressalte-se que a pretensão da pesquisa foi identificar, primordialmente, os seguintes aspectos, o que implicará na construção de múltiplas variáveis para cada uma desta dimensões: a) os entes demandados mais recorrentes, sua forma de composição e qual setor econômico pertencem; b) o motivo-objeto das ações civis públicas relacionado ao tipo de dano ambiental; c) os bens ambientais tutelados que mais figuram na causa de pedir e o município onde se situam; d) os aspectos relacionados com o tempo de tramitação processual a partir da identificação das datas relativas às decisões sobre o pedido liminar, a sentença, o trânsito em julgado da ação e o seu cumprimento; e) os dispositivos da sentença; f) os valores estipulados nas decisões a título de multa ou condenação, aplicadas em função do dano ambiental perpetrado; g) as espécies recursais porventura interpostas.

\section{Ministério Público na Constituição de 1988}

A combinação de elementos de democracia representativa e de democracia participativa, a introdução de novos direitos e a ampliação dos direitos fundamentais, concomitante aos mecanismos de participação da sociedade civil e de controle da administração pública marcaram o texto final da Constituição de 1988, fruto de compromissos políticos firmados entre as forças representadas pelos partidos políticos e diversos grupos da sociedade civil. A bem-sucedida mobilização de grupos e movimentos sociais em paralelo às propostas de atores do campo jurídico transformaram em artigos constitucionais as reivindicações e procedimentos judiciais inovadores que abriram caminho para a crescente importância política do Ministério Público e do Poder Judiciário (SILVA, 2001, p. 30).

Não obstante os riscos e críticas associados a uma hipertrofia institucional, em particular quanto aos impactos sobre os outros poderes e sobre o sistema político, é inegável o Ministério Público 
ganhou, na nova ordem constitucional, posição inédita no capítulo das funções essenciais à justiça. Dentre outras atribuições, o MP incumbe-se da defesa da ordem jurídica, do regime democrático e dos interesses sociais e individuais indisponíveis.

Para autores como Sacco (2008, p. 100), essa localização seria “[...] a mais avançada, analítica e sistemática dentre as democracias ocidentais, consolidando-se, pois, o perfil de uma instituição comprometida com o aprimoramento da democracia e com a defesa dos interesses da sociedade." Arantes (2002, p. 76), por sua vez, enxerga nesse desenho normativo o fechamento de um processo bidimensional de independência.

Diante desse novo perfil, Paulo Bonavides (2003, p. 350), com um olhar otimista e ainda no início do anos 2000, define o Ministério Público como "órgão constitucional" cabendo-lhe atuar como "o grande braço protetor da Sociedade", daí asseverar que a instituição não se vincularia a partidarismos, "nem é governo, nem oposição", mas "o Ministério Público é constitucional; é a Constituição em ação, em nome da sociedade, do interesse público, da defesa do regime, da eficácia e salvaguarda das instituições."

A associação entre um desenho institucional de grande independência e um conjunto amplo de funções e instrumentos vinculados aos fundamentos da República brasileira forjaram uma percepção dos membros do MP como espécies de "guardiões" dos direitos fundamentais. Esse tipo de visão acaba por colocar peso e expectativa excessiva na ação dos promotores e procuradores, especialmente quando se observa no plano concreto das pesquisas empíricas os limites da atuação ministerial.

Acerca da função finalística da instituição, dispôs o art. 129 da CF/88, trazendo a lume diversas atribuições e instrumentos de que necessita o MP, incumbido do papel de "dinamizar o funcionamento do sistema jurídico" e "suprir lacunas no processo de mobilização e agilização da ordem pública", daí, inobstante típica função de exercer a ação penal pública, restou esta apequenada diante da missão institucional em defesa dos interesses difusos e coletivos. "O assento natural do Ministério Público está hoje na defesa da sociedade." (BASTOS; MARTINS, 1997, p. 134).

Mazzilli (2007, p. 286) ressalta que a natureza jurídica das funções do Ministério Público "consiste no exercício de parcela direta da soberania do Estado", característica que o distingue do corpo funcional comum, vale dizer, possui regime jurídico diferenciado, bem como sua finalidade institucional é própria, dotado da autonomia típica dos Poderes do Estado, ainda com garantias e vedações semelhantes à magistratura, quais sejam, aquelas incompatíveis com sua missão constitucional.

Almeida (2013, p. 59-60) e Goulart (2013, p. 201-202) tratam a questão em perspectiva mais holística, enxergando nos dias atuais uma fase transicional do "Ministério Público demandista", anacrônica e em processo de superação, para o "Ministério Público resolutivo", em construção. Segundo o último autor, o demandista caracteriza-se por ser passivo e inoperante. Na seara cível restringe-se ao processo judicial, como mero operador processual, ora funcionando como órgão 
agente (autor de ação civil pública), ora como interveniente (custos legis). Nesse modelo, o inquérito civil reduz-se à simples instrumento de coleta de provas, transferindo-se para o Judiciário a solução de todas as questões de índole transindividual. Já o resolutivo potencializa o princípio da autonomia funcional, priorizando a solução direta das questões sociais através dos instrumentos extrajudiciais. Assume, portanto, um papel de agente político como órgão da sociedade civil na afirmação dos valores democráticos e na efetiva realização dos direitos sociais.

Cátia Aida Silva (2001, p. 164) após estudo empírico da atuação de promotores de justiça no Estado de São Paulo, no período compreendido entre 1990 e 1997, identificou uma correlação material entre "os dois tipos de MP" relatados acima. Na classificação de Aida Silva (2001, p. 164) o "resolutivo" corresponde ao "promotor de fatos", enquanto o "demandista" correlaciona-se com o "promotor de gabinete":

tipo promotor de fatos indica a tendência de alargamento das funções dos promotores para muito além da esfera jurídica, tornando-os verdadeiros articuladores políticos nas comunidades em que trabalha. $O$ tipo promotor de gabinete indica a leitura das novas atribuições do promotor dentro das fronteiras da esfera jurídica, definindo-o como agente judiciário cuja prioridade é o trabalho processual - propor e acompanhar medidas judiciais -, embora não deixe de atuar na defesa de interesses metaindividuais. De um lado, as atribuições abrangentes do Ministério Público são percebidas como fonte de poder a ser usado na transformação da sociedade. De outro, causam desconforto por causa dos limites impostos pela realidade e pelas fronteiras imprecisas entre as esferas jurídicas e política, exigindo mais do que um agente judiciário supostamente poderia e deveria fazer.

De qualquer modo, o constituinte originário alargou de maneira expressiva as funções do Ministério Público, diretamente ligadas às transformações sociais e políticas por que passou o Brasil a partir da década de 1980, prevendo um rol não exaustivo, mas desde que compatíveis com suas finalidades (art. 129, IX, da CF/88). Essa enumeração de funções seria restritamente exemplificativa (SILVA, 2007, p. 603). A intenção seria "ampliar a proteção, nunca restringi-la, quanto aos necessitados, na busca da efetivação dos meios à proteção jurisdicional sobre seus legítimos direitos." (CRETELLA JÚNIOR, 1989, p. 3331).

A promulgação do texto constitucional consolida o progresso da produção legislativa infraconstitucional incumbida da tutela de direitos coletivos e difusos (já iniciada na Lei n $7.347 / 85$ ). Uma "[...] série de interesses antes individuais e alguns até disponíveis foram convertidos em direitos de dimensão coletiva e de ordem pública, passiveis de tutela pelo Ministério Público", tomandose como critério a "indisponibilidade" ou a "incapacidade" de seus titulares de os exercerem em decorrência de hipossuficiência (ARANTES, 2002, p. 96-97).

Nesse sentido, vislumbra-se o protagonismo da ação civil pública na qualificação da tutela de direitos materiais difusos, em foco o meio ambiente, ao tempo em que se percebe a coadunação das atribuições funcionais do Ministério Público com o citado instrumento processual, encontrando na vontade do constituinte originário (art. 129, III) o anseio de concretizar a proteção desse bem, cuja 
essencialidade transcende às gerações futuras. Com efeito, essa efetividade deve ser aferida mediante pesquisa empírica que objetive analisar diversos aspectos dessa atuação ministerial, identificando as vulnerabilidades e, se possível, indicando soluções.

\section{Direito fundamental ao meio ambiente equilibrado e sua tutela por meio de ação civil pública}

Dois séculos de história da civilização industrial foram suficientes para transformar as crescentes expectativas de desenvolvimento econômico e tecnológico num enorme dilema envolvendo a sustentabilidade do planeta Terra. Alertas incisivos a partir da década de 1970 despertaram a urgência da tutela jurídica do meio ambiente equilibrado em escala global, mas também acendeu o desafio missionário às gerações presentes em legar a mesma qualidade de vida aos seus descendentes.

Nesse passo, mostra-se pertinente delinear a construção do direito material fundamental ao meio ambiente equilibrado e o tratamento da matéria no Direito Constitucional brasileiro, com enfoque especial no regime de responsabilidade civil por danos ambientais e na utilização da ação civil pública como principal instrumento jurídico de sua tutela por parte do Ministério Público.

Característicos da sociedade de massa, os chamados direitos da terceira dimensão acompanham o surgimento do Estado Democrático de Direito, legitimado na perspectiva democrática da gestão pública, ou seja, "legitimação constitucional dos atos administrativos a partir dos direitos fundamentais", considerando sua acumulação (liberais, sociais e democráticos). Com isso, alarga-se a participação para novos atores sociais reivindicarem prestações e, no tocante aos direitos difusos, demonstra-se como uma ressonância jurídica à "sociedade de risco" preconizada por Ulrick Beck (2010) (DAMANCENA; CARVALHO, 2013, p. 475-476).

A "questão ecológica" surge como um problema jurídico quando adquire conotações éticas com base numa responsabilidade ambiental global diante da crítica realidade circundante, quando o senso comum reconhece como injusta a ação que põe em risco a sobrevivência terrena, tendo em vista nada justificar a valorização das gerações presentes em detrimento das futuras. Deve-se, portanto, alterar a forma do agir individualizado, não de maneira espontânea, mas pela atuação do Estado mediante os seguintes desdobramentos: assimilação do ambiente como bem jurídico fundamental, compreensão político-jurídica do "risco" como fenômeno inerente a toda decisão (pessoal ou estatal) e garantia de futuro enquanto espaço de vida com dignidade, para além das gerações presentes (GARCIA, 2007, p. 19, 396).

De qualquer modo, essas formulações acerca do meio ambiente e sua relação intrínseca com o papel protetivo estatal faz com que Alexy (2008, p. 443) o intitule de "direito fundamental completo", por representar:

Um direito a que o Estado se abstenha de determinadas intervenções no meio ambiente (direito de defesa), um direito a que o Estado proteja o titular do direito fundamental contra 
intervenções de terceiros que sejam lesivas ao meio ambiente (direito de Proteção), um direito a que o Estado inclua o titular do direito fundamental nos procedimentos relevantes para o meio ambiente (direito a procedimentos) e um direito a que o próprio Estado tome medidas fáticas benéficas ao meio ambiente (direito à prestação fática).

Firmando-se como ciência jurídica, o Direito Ambiental ganha corpo e forma a partir da presença de um conjunto de princípios e normas específicos que o informa. Considerando a sua essência protetiva, concernindo na prioridade de se evitar agressões ao ambiente ou as causas de ações suscetíveis de modificar sua qualidade, despontam como princípios basilares a precaução e a prevenção.

Marchesan (2005, p. 30) sintetiza a distinção entre eles atribuindo à prevenção o tratamento dos riscos ou impactos já conhecidos pela ciência (risco certo ou perigo concreto), enquanto a precaução destina-se a gerir riscos ou impactos desconhecidos (risco incerto ou perigo abstrato). Noutras palavras, Milaré (2011, p. 1070-1071) aduz que a prevenção se aplica quando o perigo é certo e se pode determinar com segurança que determinada atividade se revela efetivamente perigosa, já a precaução envolver uma decisão a ser tomada quando a informação científica se mostra insuficiente, inconclusiva ou incerta e haja indicações de possíveis efeitos danosos sobre o ambiente.

Essas premissas deram o tratamento do meio ambiente na Constituição de 1988 (art. 225) mediante a ratificação da sua fundamentalidade como corolário do princípio da dignidade da pessoa humana, haja vista a abertura material do conceito de direitos fundamentais apregoados no art. $5^{\circ}$, $\llbracket 2^{\circ}$. Em decorrência dessa essencialidade do bem ambiental, o constituinte engendrou um sistema de proteção jurídica atuante nas áreas preventiva, reparatória e repressiva, mediante o princípio da responsabilização integral por danos ao meio ambiente, implicando não só na aplicação de sanções administrativas e penais, mas também o dever de reparar os danos ambientais (responsabilidade civil), que abrangem a recuperação e restauração do bem lesado; todas independentes entre si (art. 225, s $\int 2^{\circ}$ e $3^{\circ}$, da CF/88).

instituto da responsabilidade civil alcança novos patamares quando é analisado sob o prisma dos danos ao meio ambiente, segundo o qual não se restringe ao espaço da autonomia privada, mas numa redefinição ontológica em face das exigências de sua conexão com os direitos difusos moldados na soberania pública. No Brasil, Sérgio Ferraz (1977, p. 36) já alertava para a problemática da degradação ambiental como um problema mundial e a acepção do meio ambiente como um patrimônio de todos e, nessa condição, desencadearia uma flexibilização dos atributos próprios do direito de propriedade no que concerne ao seu uso (função social da propriedade). Ao que parece, essa premissa influenciou no conteúdo da Lei $n^{\circ} 6.938 / 1981$, art. $14, \mathbb{\$} 1^{\circ}$, considerada recepcionada pela Constituição Federal de 1988 em decorrência do disposto no art. 225, \$ $3^{\circ}$.

Os interesses transidividuais quando violados demandam do aparelhamento estatal as medidas necessárias à sua cessação e restauração da ordem jurídica e da recomposição dos bens vilipendiados (mesmo pela via indenizatória), valendo-se dos instrumentos jurídicos cabíveis, 
principalmente nas searas administrativa e jurisdicional (poder/dever de ação). Em vista disso, é possível a utilização de instrumentos processuais e extraprocessuais na tutela do meio ambiente, importando fazer menção neste tópico apenas àqueles utilizados pelo MP. No último caso destacamse o inquérito civil (IC) e o termo de ajustamento de conduta (TAC) e, perante o Judiciário, a ação civil pública.

O inquérito civil surge com o advento da Lei $\mathrm{n}^{\circ} 7.347 / 85$, posteriormente alçado à condição de instrumento constitucional de investigação (art. 129, III, da CF/88) à disposição exclusiva do Ministério Público, para obtenção de elementos de convicção do qual poderá resultar a propositura de ação civil pública ou a celebração de compromisso de ajustamento de conduta. De natureza inquisitiva e dispensável quando por outros meios de convicção se obtenha os elementos necessários para os fins colimados, não se cogita no inquérito civil a incidência dos princípios do contraditório e da ampla defesa ou qualquer necessidade de deferimento do judiciário para seu desenvolvimento (VIGLIAR, 2001, p. 127-132).

A instauração do inquérito civil realiza-se mediante atuação de ofício, quando o membro do MP toma ciência de fato que afete interesse metaindividual para os quais esteja legitimado a agir; ou por despacho de autuação exarado nos requerimentos e/ou representações que adentram na instituição por interessados, pessoas físicas ou entidades. Para o seu desenvolvimento regular (instrução), dispõe o Parquet de poderes requisitórios (art. $8^{\circ}, \mathbb{S} 1^{\circ}$, da LACP) que visam apurar materialidade e autoria de atos lesivos de sua competência tutelar, sob pena de imputação de crime de desobediência ao ente requerido e que injustificadamente não preste as informações (Art. 10 da LACP). À vista disso, o órgão de execução (MP) encontra-se adstrito ao poder-dever de investigar, não lhe cabendo juízo de oportunidade e conveniência, como também deverá fundamentar e dar publicidade das suas decisões, desde a autuação até o arquivamento.

O TAC foi enxertado na LACP pela Lei no 8.078/90, mediante a inclusão do $\$ 6^{\circ}$ ao art. 5०: "Os órgãos públicos legitimados poderão tomar dos interessados compromisso de ajustamento de sua conduta às exigências legais, mediante cominações, que terá eficácia de título executivo extrajudicial." Vê-se que o MP não ostenta exclusividade da utilização desse instrumento, cabendo a qualquer colegitimado (órgão público) sua utilização, mesmo sem a instauração de inquérito civil. Outra vantagem evidente repousa na sua natureza jurídica, constituindo, de pronto (sem necessidade de homologação judicial), título executivo extrajudicial no caso de inobservância dos seus termos. Neste caso, dispensado está o processo de conhecimento, partindo-se diretamente à ação executiva pelo promitente em face do compromissário.

Pela própria natureza de alguns interesses transindividuais, nem sempre torna-se possível à celebração de TAC, mas interessando de perto a matéria ambiental, o termo também não deve prescindir da indisponibilidade característica desse bem, devendo conter proposta equivalente ao objeto de uma ação civil pública. As convenções firmadas ficariam restritas às condições de cumprimento das obrigações (modo, tempo, lugar etc.), levando-se em conta as especificidades do 
caso concreto, a capacidade econômica do infrator e os interesses da sociedade (MILARÉ, 2010, p. 981). A realização do TAC, embora costumeiramente ocorra em sede extrajudicial, não há empecilho para a celebração na seara jurisdicional, no bojo da ação civil púbica.

Por sua vez, a tutela jurisdicional coletiva quebra três paradigmas do sistema clássico caracterizado pela "singularidade" na interpretação de Cândido Dinamarco (1995, p. 26):

a) a legitimidade para agir necessariamente individual;

b) a limitação invariável dos efeitos diretos da sentença às partes do processo;

c) a rigorosa limitação subjetiva da autoridade da coisa julgada, ou seja, quem se sujeitará a imutabilidade da sentença.

Nesses pontos, rompe-se a mentalidade individualista marcante no sistema processual brasileiro. O passo inicial adveio com a edição LACP que, segundo o autor, pretendia oferecer proteção aos valores ambientais, em complementação ao direito material estatuído na Lei da Política Nacional do Meio Ambiente (Lei n ${ }^{\circ}$ 6.938/81).

Quanto à legitimação ativa na ACP, mesmo não sendo o Ministério Público o único ente contemplado (art. $5^{\circ}$ da LACP), seu protagonismo desponta não só pela destinação constitucional do manejo da ação civil pública como função institucional (art. 129, III), mas também pela sua interveniência obrigatória, quer seja na qualidade de autor ou na condição de fiscal da lei (art. $5^{\circ}, \mathbb{S}$ $1^{\circ}$ da LACP). Ainda poderá assumir a titularidade ativa da ação em caso de desistência infundada ou abandono por associação legitimada $\left(\operatorname{art} .5^{\circ}, \mathbb{\$} 3^{\circ}\right.$ ), formar litisconsórcio facultativo entre os seus ramos - Ministérios Públicos da União, do Distrito Federal e dos Estados (art. $5^{\circ}, \mathbb{\$} 5^{\circ}$ ) e promover a execução do julgado nos casos em que a associação legitimada não o faça após sessenta dias do trânsito em julgado (art. 15).

Na seara ambiental, o MP possui legitimidade para todas as situações materiais pretendidas, isto é, no que dizem respeito à "prevenção" de danos ambientais (realização de atividades efetiva ou potencialmente poluidoras e de riscos ou perigos danosos ao meio ambiente), à "cessação" de atividades, atos ou omissões efetivas ou potenciais de degradação; à "reparação" de danos ambientais e, ainda, a adoção de providências urgentes. Daí, fala-se em tutelas "preventiva" e de "cessação", "reparatória" (in natura e pecuniária) e de "urgência", todas possíveis pela via da ACP (MIRRA, 2004, p. 80).

A ação civil pública ambiental será proposta em face do poluidor, pessoa física ou jurídica, individualmente considerado ou em litisconsórcio, na condição de responsável direto ou indireto, ou contra ambos (responsabilidade solidária). A Lei no 9.605/98 prevê que a responsabilidade das pessoas jurídicas não exclui a das pessoas físicas, autoras, coautoras ou participantes do mesmo fato (art. $3^{\circ}$ e parágrafo único), como também poderá ser desconsiderada a pessoa jurídica sempre que sua 
personalidade for obstáculo ao ressarcimento de prejuízos causados à qualidade do meio ambiente $\left(\operatorname{art} .4^{\circ}\right)$.

Em regra, as ações civis públicas são propostas no foro do local onde ocorreu o dano e o juízo deterá competência funcional para processar e julgar a causa (art. $2^{\circ}$ da LACP). Portanto, o ajuizamento da ação em foro diverso pode ensejar a nulidade dos atos decisórios (art. 113, $\mathbb{2} 2^{\circ}$, do CPC). Se o dano ocorrer em território que envolva duas comarcas ou mais, a prevenção será fixada pela prevenção, com o ajuizamento da ação, em relação às outras demandas propostas posteriormente com mesma causa de pedir ou pedido (art. $2^{\circ}$, parágrafo único, da LACP). Contudo, sendo o dano de alcance regional (envolvendo mais de um estado-membro), a competência deve ser deslocada para a Justiça Federal por força do art. 109, $\$ 3^{\circ}$, da CF/88.

A atuação do MPF fica adstrita à tutela dos bens de interesse da União (art. 20, da CF/88), suas autarquias e empresas públicas e o foro competente é a Justiça Federal (art. 109, I, da CF/88). Essa hipótese constitui exceção à regra geral da competência em decorrência do local do dano, como também quando houver interesse de dois ou mais estados da federação (art. 102, I, f, da CF/88). Desta maneira, na seara ambiental, possuindo o Instituto Brasileiro do Meio Ambiente (IBAMA), autarquia federal dotada de personalidade jurídica de direito público, interesse na lide, o feito deve ser processado e julgado perante a Justiça Federal. Já a autoria autônoma do MPF na lide contra particulares na jurisdição federal, ou seja, sem a participação da União, suas autarquias e empresas públicas, nem sempre foi pacífica.

Regulamentando o disposto no art. 23, III, VI e VII, da CF/88, que estabelece a competência comum da União, dos Estados, do Distrito Federal e dos Municípios à proteção do meio ambiente, a Lei Complementar n 140/2011 fixou e sistematizou diversas ações administrativas com influência na atuação do MPF em matéria ambiental, e, consequentemente, na seara jurisdicional. Embora tenha previsto instrumentos de cooperação entre os entes federativos, a lei em referência estabeleceu um rol estanque de ações administrativas para a União (art. $7^{\circ}$ ) e Municípios (art. $9^{\circ}$ ), ficando os Estados com a competência residual (art. $8^{\circ}$ ).

Havendo numerário pago pelos poluidores, esse valor se reverterá ao Fundo de Defesa de Direitos Difusos, previsto no art. 13 da LACP e que encontra regulamentação na esfera federal na Lei $n^{\circ} 9.008 / 95$ e no Decreto no $1.306 / 94$. O produto da arrecadação de que se cuida deve ser utilizado prioritariamente na reparação específica do prejuízo que deu origem à condenação no local de sua ocorrência, ficando as medidas a serem adotadas vinculadas à sentença judicial proferida. Desse modo, não há espaço para discricionariedade do organismo gestor do fundo para empregar a soma obtida em medidas diversas (MIRRA, 2004, p. 363).

Realizado o intento de demonstrar o protagonismo da ação civil pública na qualificação da tutela de direitos materiais difusos, em foco o meio ambiente, percebe-se que a coadunação das atribuições funcionais do Ministério Público com o citado instrumento processual encontra na vontade do constituinte originário (art. 129, III) o anseio de concretizar a proteção desse bem, cuja 
essencialidade transcende às gerações futuras. Com efeito, essa efetividade deve ser aferida mediante pesquisa empírica que objetive analisar diversos aspectos dessa atuação ministerial, identificando as vulnerabilidades e, quando possível, indicar soluções.

\section{A atuação do Ministério Público Federal no Estado do Ceará na tutela jurisdicional do meio ambiente por meio da ação civil pública}

O estudo sobre a atuação do MPF na tutela ambiental ocorreu por meio de pesquisa empírica em que foram analisadas todas as ações civis públicas ajuizadas na Justiça Federal na jurisdição da cidade de Fortaleza. Optou-se por utilizar a ACP por se tratar do principal instrumento jurídico para tutelar matéria relativa ao meio ambiente. Adotou-se um recorte temporal de cinco anos (2009 a 2013), a fim de permitir uma análise mais profunda em ações. Com este período, tornou-se possível observar as ações em todos os seus procedimentos e incidentes, avaliando as posições e iniciativas do MP, do Judiciário e dos demais envolvidos.

Para isso, recorreu-se aos registros processuais do banco de dados do sistema eletrônico do MPF (Sistema Único) em cotejo com os arquivos correspondentes às digitalizações de todas as ações civis públicas. Realizada a seleção das ações civis públicas que versavam sobre matéria ambiental, chegou-se ao quantitativo de 238 processos dessa natureza no quinquênio referido. Passo seguinte, eis que foi elaborado um questionário com quesitos contemplando variáveis necessárias à composição do banco de dados.

Deu-se especial atenção aos quesitos relativos às datas dos registros processuais para avaliar a resposta jurisdicional aos pedidos do $\mathrm{MP}$, primordialmente, no tocante ao atendimento ao princípio da duração razoável do processo (art. $5^{\circ}$, LXXVII, da CF/88). Atentou-se também para a identificação dos réus, a iniciativa para a instauração do procedimento administrativo ou inquérito civil sobre a matéria versada no âmbito do MPF, a ação ou omissão perpetrada pelo(s) demandado(s) plasmada na causa de pedir e no pedido, a identificação do município pertencente à jurisdição de Fortaleza onde se constatou o dano ambiental, e por último a análise do conteúdo das decisões prolatadas, quer sejam em sede liminar, sentença ou acórdãos do TRF $5^{\text {a }}$ Região.

Para composição do banco de dados, as informações foram coletadas utilizando-se o seguinte procedimento: os arquivos eletrônicos (pdf) de cada processo eram analisados, principalmente a petição inicial, medida suficiente, na maioria das vezes. Diante da insuficiência de dados, recorriase ao sistema interno de registro e acompanhamento administrativo e processual do MPF (Sistema Único). Para a coleta dos dados remanescentes, pesquisava-se nos sítios eletrônicos da Justiça Federal no Estado do Ceará e do Tribunal Regional Federal da $5^{\text {a }}$ Região na internet.

Os dados foram agrupados para produzir resultados em três seções: a) resultados decorrentes de variáveis unitárias - que permitiu extrair conclusões sobre cada variável e apresentar uma visão geral dos assuntos pesquisados; b) resultados dos dados envolvendo o trâmite processual - 
como dito, oportunizou avaliar o tempo de resposta jurisdicional aos pedidos ministeriais e analisálo sob o prisma do princípio constitucional da razoável duração do processo; c) resultados de dados cruzados de duas variáveis - essas interseções buscaram identificar as vinculações características da atuação do MP que embasaram as conclusões gerais do presente trabalho. Para a análise foi utilizado o programa SPSS.

\section{Resultados decorrentes de variáveis unitárias}

Inicialmente, apresentam-se os resultados obtidos na pesquisa por meio de tabulações e gráficos dos dados contendo variável única: a) ano de autuação da ACP; b) composição do polo passivo (individual ou litisconsórcio), c) natureza jurídica do réu (ou do primeiro réu no litisconsórcio); d) iniciativa para instauração de Procedimento Administrativo (PA) ou Inquérito Civil (IC) que resultou no ajuizamento da ACP; e) setor econômico do réu; f) motivo ou objeto da ACP; g) bem ambiental protegido; e h) município onde se localiza o bem ambiental.

\begin{tabular}{ccr}
\multicolumn{3}{c}{ Tabela $1-$ Ano de autuação da ACP (2009 a 2013) } \\
\hline Ano & Frequência & \multicolumn{2}{c}{ Percentual } \\
\hline 2013 & 54 & 22,7 \\
2012 & 38 & 16,0 \\
2011 & 44 & 18,5 \\
2010 & 61 & 25,6 \\
2009 & 41 & 17,2 \\
\hline Total & $\mathbf{2 3 8}$ & $\mathbf{1 0 0 , 0}$ \\
\hline Fonte: os autores.
\end{tabular}

Nessa apuração constatou-se pequena variação no número de processos autuados por ano, com maior discrepância no exercício de 2010, por representar um quarto do total. Essas variações decorrem, em maior medida, da proporção das remessas dos órgãos ambientais (especialmente o federal - IBAMA) ao MPF/CE, conforme será relatado na Tabela 4. Encaminhadas as autuações oriundas de infrações ambientais por esses órgãos, o Parquet federal instaura Procedimento Administrativo (PA) ou Inquérito Civil (IC) para apurar responsabilidade civil do degradador, dos quais resulta o ajuizamento de ACP.

Portanto, embora não seja o único fator determinante, mas o principal, o número de comunicados do IBAMA ao MPF exerce influência diretamente proporcional na quantidade de ACPs ambientais.

Outro elemento importante de influência nesse quantitativo anual decorre do desmembramento do PA ou IC por ocasião da conclusão da sua instrução. A apuração dos elementos de autoria e materialidade às vezes revela um grande número de pretensos demandados em ACP. 
A formação de litisconsórcio com maior número de réus favorece a lentidão e o tumulto da marcha processual, naturalmente ocasionados pela composição plural. Desse modo, identificados todos os responsáveis pela degradação ambiental em um único PA ou IC, e, sendo possível a individualização da conduta, geralmente o MPF ajuíza tantas ações quantos forem os requeridos, particularizando as demandas e anexando cópia desses procedimentos em cada ação. Assim, por exemplo, um único IC cujo objeto alcançou as barracas ilegalmente encravadas em faixa de praia na orla do Município de Cascavel, no distrito de "Praia da Caponga", propiciou o aforamento de diversas ACPs conforme o número de proprietários dessas instalações.

Tabela 2 - Composição do polo passivo

\begin{tabular}{lrr}
\hline \multicolumn{1}{c}{ Composição do polo passivo } & Frequência & \multicolumn{2}{c}{ Percentual } \\
\hline Réu individual & 168 & $\mathbf{7 0 , 6}$ \\
Litisconsórcio passivo & 70 & 29,4 \\
\hline Total & $\mathbf{2 3 8}$ & $\mathbf{1 0 0 , 0}$ \\
\hline Fonte: os autores. & &
\end{tabular}

A forma de peticionar por autuação individualizada, em referência no item anterior, influenciou a composição do polo passivo, protagonizada por réu individual (70\%) em detrimento da formação de litisconsórcio (30\%). A composição plural do polo passivo compreendeu mais as situações em que se mostrava necessária a junção na mesma demanda do(s) poluidor(es) e dos órgãos públicos responsáveis pelo licenciamento de obras ou empreendimentos específicos. Da disposição litisconsorcial pesquisada, apenas 11,3\% apresentou três ou mais réus no total de ações.

Tabela 3 - Natureza jurídica do réu (ou primeiro réu no litisconsórcio)

\begin{tabular}{lrr}
\hline \multicolumn{1}{c}{ Natureza Jurídica } & Frequência & Percentual \\
\hline Pessoa jurídica de direito público & 24 & 10,1 \\
Pessoa natural & 168 & 70,6 \\
Pessoa jurídica de direito privado & 46 & 19,3 \\
\hline Total & $\mathbf{2 3 8}$ & $\mathbf{1 0 0 , 0}$ \\
\hline Fonte: os autores. &
\end{tabular}

Nesse caso, constatou-se uma maioria expressiva da categoria "pessoa natural" (70,6\%) sobre as demais "pessoa jurídica de direito privado" (19,3\%) e "pessoa jurídica de direito público" $(10,1 \%)$.

Ratificando o que já fora exposto sobre a individualização dos réus, percebeu-se que essa primazia decorreu de atividades comerciais exercidas por pessoa natural em "barracas de praia" em áreas não edificáveis (sem registro de pessoa jurídica), na pesca e comercialização de lagosta em período de defeso ou em fase prematura (dimensões abaixo das especificações legais) e na extração de areia de forma ilegal. 
A participação de pessoa jurídica de direito privado vincula-se mais às atividades de construção de empreendimentos em áreas não edificáveis, como dunas, faixa de praia, manguezais, dentre outros, ou provocando desmatamentos. Como dito, os órgãos públicos são demandados com maior frequência quando o assunto envolve a concessão de licenças reputadas irregulares ou ilegais.

\begin{tabular}{lrr} 
Tabela 4 - Iniciativa de instauração de Procedimento Administrativo (PA) ou Inquérito Civil (IC) \\
\hline \multicolumn{1}{c}{ Iniciativa do PA ou IC } & Frequência & Percentual \\
\hline Remessa de órgão ambiental & 173 & 72,7 \\
Cidadão ou organização da sociedade civil & 39 & 16,4 \\
Autuação de ofício por membro do MPF & 14 & 5,9 \\
Outros órgãos públicos (DNPM, MPE, etc.) & 6 & 2,5 \\
Informação não disponível & 6 & 2,5 \\
\hline Total & $\mathbf{2 3 8}$ & $\mathbf{1 0 0 , 0}$ \\
Fonte: os autores. & &
\end{tabular}

Os órgãos ambientais dos entes federativos, vale dizer: Instituto do Meio Ambiente e dos Recursos Naturais Renováveis (IBAMA), no âmbito da União; a Superintendência Estadual do Meio Ambiente do Estado do Ceará (SEMACE), no âmbito estadual; e a Secretaria Municipal de Urbanismo e Meio Ambiente (SEUMA), antiga Secretaria Municipal de Meio Ambiente e Controle Urbano (SEMAM), na circunscrição municipal; exercem o poder de polícia nas suas respectivas competências e encaminham ao MPF o resultado das autuações quando há interesse da União consubstanciado no bem ambiental protegido, principalmente o IBAMA. Esse fato motiva o elevado percentual de iniciativa de procedimentos no Parquet (73\%), haja vista a intensidade do serviço de fiscalização realizado por esses órgãos.

Sobressai neste dado a dependência do MPF em relação aos procedimentos adotados pelos órgãos de fiscalização. O maior ou menor número de ações depende diretamente das iniciativas externas ao MP e, em última instância, por políticas e determinações oriundas do Executivo. Essa informação leva à necessidade e refletir sobre o papel do MP na formulação destas políticas relacionadas à proteção ao meio ambiente, bem como aprofundar a análise sobre a importância de ações preventivas, em conformidade com os princípios do Direito Ambiental.

A participação da sociedade realiza-se basicamente por duas vias. A primeira por denúncia ou representação via internet no sitio eletrônico da Procuradoria da República no Estado do Ceará (PR/CE), no espaço "para o cidadão", e em seguida "registrar denúncia ou solicitação".

A outra forma efetiva-se na representação escrita pelo próprio interessado e protocolado na sede da PR/CE ou, com o mesmo efeito, reduzida a termo no setor competente (Serviço de Atendimento ao Cidadão - SAC), disponibilizado pelo órgão ao cidadão que não opte em efetuar os outros procedimentos. Entretanto, em todos os casos não há necessidade de identificação do representante como condição para que o procedimento seja instaurado, ficando todas as análises de prosseguimento do feito por conta do procurador natural. 
Já o membro do MPF participa da inciativa da instauração em comento quando toma conhecimento de fatos supostamente danosos ao meio ambiente, em geral por meio de comunicações informais ou pelos canais midiáticos (jornais, televisão, rádio, internet etc.). Com efeito, exara despacho de autuação tratando-se de matéria impressa ou edita Portaria de instauração de PA ou IC, na qual faz breve relato dos fatos que tomou conhecimento.

Por fim, a inciativa de outros órgãos públicos (não ambientais) foi determinada pela remessa de peças de informações por outros ramos do Ministério Público (como o Ministério Público Estadual) e por aqueles que exercem poder de polícia, a exemplo do Departamento Nacional de Produção Mineral (DNPM), autarquia federal.

\begin{tabular}{lrr} 
Tabela 5 - Setor econômico do réu (ou primeiro réu no litisconsórcio) & \\
\hline Setor econômico do réu & Frequência & Percentual \\
\hline Comércio & 76 & 31,9 \\
Indústrias & 3 & 1,3 \\
Hotelaria - imobiliário & 12 & 5,0 \\
Pesca & 12 & 5,0 \\
Construção & 13 & 5,5 \\
Serviço público & 21 & 8,8 \\
Outros & 17 & 7,1 \\
Informação não disponível & 84 & 35,3 \\
\hline Total & $\mathbf{2 3 8}$ & $\mathbf{1 0 0 , 0}$ \\
Fonte: os autores. & &
\end{tabular}

Quanto a esse quesito, houve dificuldade na identificação em aproximadamente $35 \%$ dos casos. A causa está ligada ao fato de não se evidenciar esse dado na leitura da petição inicial, sendo necessário esquadrinhar todo procedimento que embasou a ACP, o que somente seria possível com o acesso físico dos autos.

De qualquer modo, o ramo comercial desponta na liderança desse quesito com um percentual de quase $32 \%$ do total, em cotejo com as demais atividades privadas como hotelaria, pesca e construção que oscilaram entre 5\% e 5,5\%. O baixo percentual das indústrias (1,3\%) denota que a área geográfica de atuação desse segmento guarda pouca correlação com as decorrentes do interesse da União em matéria ambiental, e, por via atrativa, atenua os casos de competência do MPF.

O percentual do serviço público (8,8\%) representa o quantitativo de demandas vinculadas à participação dos entes estatais como réus individuais ou como primeiro réu nos litisconsórcios, quer seja diante de omissões que propiciem a ocorrência de danos ambientais, ou em decorrência de ato comissivo, induzindo ou facilitando a degradação do meio ambiente nas suas respectivas áreas de competência. 
Os casos mais recorrentes na causa de pedir, de acordo com a pesquisa, dizem respeito a impugnações de licenciamentos reputados irregulares ou ilegais, ou na omissão do poder público no poder-dever de fiscalizar e punir os responsáveis pelas condutas danosas ao meio ambiente.

\begin{tabular}{lrr} 
Tabela 6 - Motivo ou objeto da ACP & & \\
\hline \multicolumn{1}{c}{ Motivo ou objeto da ACP } & Frequência & Percentual \\
\hline Desmatamento & 21 & 8,8 \\
Poluição & 6 & 2,5 \\
Pesca ou comércio ilegal & 28 & 11,8 \\
Área não edificável & 144 & 60,5 \\
Extração mineral & 15 & 6,3 \\
Licenciamento & 14 & 5,9 \\
Outros & 10 & 4,2 \\
\hline Total & $\mathbf{2 3 8}$ & $\mathbf{1 0 0 , 0}$ \\
Fonte: Os autores. & &
\end{tabular}

A motivação do ajuizamento da ACP reflete as circunstâncias das ilicitudes perpetradas pelos réus com relação aos bens ambientais protegidos. A atenção recai sobre as áreas não edificáveis (especialmente Área de Preservação Permanente - APP), representando aproximadamente 60\% do total. Atribui-se essa frequência ao número expressivo de ocupações em terreno de marinha ou faixa de praia no litoral cearense, em decorrência de especulação imobiliária (construções) e na exploração de atividade econômica, como visto, de barracas de praia. A pesca e/ou comercialização da lagosta em tempo de defeso ou em fase prematura é responsável por cerca de $11 \%$ das lides, uma vez que responde pela quase totalidade dos casos dessa natureza. Os poucos eventos não vinculados a essa prática estão voltados à forma e aos instrumentos utilizados na pesca no litoral do Estado.

\begin{tabular}{lrr} 
Tabela $7-$ Bem ambiental protegido & & \\
\hline \multicolumn{1}{c}{ Bem ambiental } & Frequência & Percentual \\
\hline Dunas & 31 & 13,0 \\
Faixa de praia ou terreno de marinha & 51 & 21,4 \\
Mangue & 32 & 13,4 \\
Flora & 10 & 4,2 \\
Fauna & 30 & 12,6 \\
Minérios & 18 & 7,6 \\
Água & 50 & 21,0 \\
Outros & 14 & 5,9 \\
Não se aplica & 2 & $\mathbf{0 , 8}$ \\
\hline Total & $\mathbf{2 3 8}$ & $\mathbf{1 0 0 , 0}$ \\
\hline
\end{tabular}

Fonte: os autores.

Com relação aos bens ambientais tutelados em ACP, o destaque da atuação do MPF recai sobre aqueles que estão relacionados diretamente à região litorânea, mormente faixa de praia - 
terreno de marinha, dunas (vegetadas ou não, móveis ou fixas), mangue, fauna (devido à pesca de lagosta). Em conjunto, o cômputo desses elementos corresponde a 60,4\% do total das ações, sem prejuízo da ocorrência desse tipo nas outras categorias. No entanto, observou-se que as ações cujo objeto pretendia-se a tutela da água, essas não foram originárias de danos ao mar e sim na proteção das margens de um açude (APP) na localidade de "São Mateus", no Município de Canindé/ CE, administrado pelo Departamento Nacional de Obras Contra as Secas - DNOCS. Na qualidade de autarquia federal, o interesse da União mostra-se patente e, consequentemente, a atuação do MPF. Quanto à proteção aos recursos minerais, as ações estão voltadas, em sua totalidade, aos fatos ligados à extração ilegal de areia, basicamente em decorrência de fiscalizações realizadas pelo DNPM e encaminhadas as autuações respectivas ao MPF.

\begin{tabular}{lrr} 
Tabela 8 - Município onde se localiza o bem ambiental protegido & \\
\hline Município do bem & Frequência & Percentual \\
\hline Fortaleza & 48 & 20,2 \\
Canindé & 15 & 6,3 \\
Aquiraz & 35 & 14,7 \\
Caucaia & 29 & 12,2 \\
Cascavel & 53 & 22,3 \\
Eusébio & 7 & 2,9 \\
Paracuru & 6 & 2,5 \\
São Gonçalo do Amarante & 7 & 2,9 \\
Outros & 20 & 8,4 \\
Informação não disponível & 18 & $\mathbf{7 , 6}$ \\
\hline Total & $\mathbf{2 3 8}$ & $\mathbf{1 0 0 , 0}$ \\
Fonte: os autores. & &
\end{tabular}

A distribuição dos municípios nesse item reflete o que foi dito anteriormente sobre a tutela da orla marítima do Estado do Ceará pelo MPF. Exceto os registros no Município de Canindé, motivados pelo exercício da via atrativa da União, como já referenciado no tópico anterior, os demais municípios encontram-se na região litorânea do estado. É nesse espaço geográfico que se concentra boa parte dos bens de interesse da União, conforme arrolamento da Tabela anterior e que despertam maior atração pela atividade econômica, motivada, por exemplo, pelas belezas naturais da região, exploração de comércio, serviços e especulação imobiliária. A soma das ocorrências em Cascavel, Fortaleza, Aquiraz e Caucaia resulta no percentual de 69,4\%, do total das ações. Conclui-se, portanto, que dos 34 municípios componentes da jurisdição Fortaleza, 4 deles (12\%) são responsáveis por quase 70\% das ACPs ajuizadas no quinquênio 2009-2013. O registro considerável de "informação não disponível" (7,6\%) nesse item diz respeito, principalmente, aos casos de comercialização ilegal de lagosta no continente, em que se desconhece a localidade onde foram apreendidas ou presume-se que foram capturadas no mar territorial. 


\section{Resultados dos dados envolvendo o trâmite processual}

Nesta seção serão apresentados os resultados envolvendo as fases processuais que implicam pronunciamentos do julgador objetivando à tutela do bem ambiental respectivo, quer seja em sede liminar, por ocasião da prolação de sentença ou se a matéria alcançou o patamar da segunda instância. Serão avaliados: o tempo médio de resposta a esses pedidos, o valor médio das condenações pecuniárias e o conteúdo do dispositivo das sentenças.

Tabela 9 - Pedido de liminar na petição inicial

\begin{tabular}{lrr}
\hline Houve pedido de liminar? & Frequência & Percentual \\
\hline Não & 122 & 51,3 \\
Sim & 116 & 48,7 \\
\hline Total & 238 & 100,0 \\
\hline Fonte: os autores. & &
\end{tabular}

Caracterizada a tutela ambiental como essencialmente preventiva (princípios da precaução e da prevenção), pois o caráter reparador é aplicado em última análise, é presumível que o pedido liminar em ACP pelo MPF expresse a urgência necessária para colher provimento jurisdicional inibitório ou obrigação de fazer urgente na tentativa de resguardar a incolumidade de algum bem ambiental. Há casos, porém, que o pedido restringe-se ao aspecto condenatório indenizatório, tendo em vista a irreversibilidade da ação degradadora, como é o caso do pescado apreendido e comercializado de forma ilegal. Sendo assim, entenderam os membros do MPF/CE que haveria a necessidade da tutela de urgência em praticamente metade das ações. A forma como o Judiciário reagiu a esses pedidos será analisada na próxima tabela.

Tabela 10 - Decisão sobre o pedido liminar requerido na inicial

\begin{tabular}{lrrc}
\hline Decisão do pedido liminar (total 116) & Frequência & Percentual & Tempo médio da decisão liminar \\
\hline Não apreciado & 83 & 71,5 & 7,4 meses ou 222 dias \\
Pendente de decisão & 1 & 0,9 & Valor médio multa liminar \\
Indeferimento & 11 & 9,5 & R $\$ 3.240,00$ \\
Deferimento total ou parcial & 21 & 18,1 & $\mathbf{1 0 0 , 0}$ \\
\hline Total & $\mathbf{1 1 6}$ &
\end{tabular}

Dos 116 pedidos liminares, 83 (71,5\%) não foram apreciados, isto é, o Juízo competente não se pronunciou sobre o pedido liminar nem antes (sem a oitiva da parte contrária) e nem depois da composição da relação processual, dando início à fase de instrução ou prolatando a sentença sem pronunciamento sobre tal pedido. Se somados com os registros de "indeferimento", os pedidos liminares requeridos pelo MPF resultam num percentual de $81 \%$ de insucesso. 
Ademais, dentre os deferimentos (18,1\%), há de se considerar ainda os casos em que a anuência foi apenas parcial. Conclui-se, destarte, que os pedidos ministeriais de provimento de urgência em matéria ambiental, nos casos estudados, não encontram correspondência, em sua grande maioria, com o entendimento dos julgadores.

A variável "tempo" também não foi favorável à pretensão do MPF. Do reduzido percentual de deferimentos, apurou-se que essas decisões duram em média 222 dias. A média das multas em sede liminar ficou em $\mathrm{R} \$ 3.240,00$, registradas em 5 dos 21 deferimentos (23,8\%).

Tabela 11 - Informações sobre as sentenças

\begin{tabular}{lccc}
\hline Houve sentença? & Frequência & Porcentual & $\begin{array}{c}\text { Tempo médio da sentença } \\
\text { (duração do processo na 1 }{ }^{\mathrm{a}} \text { instância) }\end{array}$ \\
$\begin{array}{lccc}\text { Não } & 128 & 53,8 & 20,93 \text { meses ou 1,74 anos } \\
\text { Sim } & 110 & 46,2 & \text { Valor médio da condenação } \\
\text { na sentença }\end{array}$ \\
Total & 238 & 100,0 & $\mathrm{R} \$ 26.852,80$ \\
\hline
\end{tabular}

Fonte: os autores.

Em foco a análise da prestação jurisdicional na primeira instância, realizada mediante a prolação da sentença, constatou-se que menos da metade dos casos (46,2\%) foram julgados.

O tempo médio de duração destes processos sentenciados nessa instância (considerando o interstício: data de autuação - data da sentença) foi de 21 meses ou 1,74 anos.

O valor médio da condenação pecuniária ficou em torno de $\mathrm{R} \$ 26.800,00$. Percebeu-se que um dos elementos catalisadores dessa demora reside na instrução do feito, tendo em vista que em muitos casos os julgadores reputam necessária a produção de prova pericial por envolver questões técnicas específicas alheias ao conhecimento do juiz. Nesse sentido, observou-se que os processos envolvendo apenas condenação pecuniária tramitaram de forma mais célere.

Tabela 12 - Conteúdo do dispositivo da sentença

\begin{tabular}{lrr}
\hline Conteúdo da sentença (110 casos) & Frequência & Percentual \\
\hline Obrigação de não fazer e condenação pecuniária & 1 & 0,9 \\
Recomposição e condenação pecuniária & 6 & 5,4 \\
Extinção do processo & 25 & 22,7 \\
Improcedência & 23 & 21 \\
Obrigação de fazer (difer. de recomposição) & 3 & 2,7 \\
Obrigação de não fazer & 2 & 1,8 \\
Condenação pecuniária & 16 & 14,5 \\
Recomposição & 34 & 31 \\
\hline Total & $\mathbf{1 1 0}$ & $\mathbf{1 0 0 , 0}$ \\
Fonte: Os autores. &
\end{tabular}


Apreciando o conteúdo do total das sentenças prolatadas (110), cabe apurar os casos de deferimento e os casos de insucesso da pretensão ministerial. Neste último estão agrupadas as decisões de "extinção do processo" (25) e "improcedência" (23).

Com efeito, o percentual de insucesso é de $43,7 \%$, enquanto o de êxito é de $57,3 \%$. O número de êxitos (62) em relação ao total de processos pesquisados (238) resulta em aproximadamente $26 \%$. Isso equivale a dizer que de todas as ações ajuizadas no período estudado, o MPF teve sua pretensão acolhida (mesmo que parcial) na primeira instância jurisdicional, em praticamente um quarto das demandas.

Apesar da prevalência de sentenças condenatórias, chama atenção o número elevado de decisões contrárias a MP ou de extinção. $\mathrm{O}$ que poderia ser lido como um sucesso, indica a necessidade de se refletir sobre a eficácia dos procedimentos utilizados, tendo em vista o número pequeno de ações propostas e a quantidade potencialmente elevada de lesões que nem sequer chegam ao MP.

Os dispositivos das sentenças mais recorrentes nos casos de êxito da pretensão do MPF estão voltados à "recomposição" (34 casos - 31\%) e à "condenação pecuniária" (16 casos - 14,5\%). Juntos respondem por quase metade dos julgados (50 casos - 45,5\%) e em relação aos registros de sucesso (62) representam 80,6\%. As outras espécies condenatórias somam aproximadamente 11\% do total.

Prevalece, dessarte, o entendimento mais conservador de se peticionar as condenações em modelos estanques: prioridade na recomposição do bem lesado (se as condições materiais são ainda propícias) e, na impossibilidade da primeira, condenação pecuniária como forma de não deixar impune o degradador.

Tabela 13 - A ACP na segunda instância (registro de 55 apelações)

\begin{tabular}{lll}
\hline Quem apelou? & Houve decisão $\mathbf{2}^{\mathbf{a}}$ instância? & Conteúdo da decisão (acórdão) \\
\hline polo ativo & Sim -29 casos & - confirmou a sentença -24 casos \\
29 casos $-52,7 \%$ & Não -26 casos & - modificou a sentença -03 casos \\
polo passivo & & - outros - 02 casos \\
26 casos $-47,3 \%$ & & \\
Fonte: os autores. &
\end{tabular}

A configuração do quadro acima demonstra que das 110 sentenças prolatadas nas ações civis públicas analisadas, houve impugnação com recurso de apelação em 50\% delas. Registrou-se um relativo equilíbrio numérico no volume apelado pelas partes, consignando no polo ativo (MPF) um adicional de apenas três casos. $\bigcirc$ Tribunal Regional Federal da $5^{\text {a }}$ Região julgou pouco mais da metade $(52,7 \%)$ dos recursos. A constatação mais relevante, entretanto, envolve a tendência do Tribunal em não modificar o mérito prolatado na decisão monocrática em primeira instância. Os termos do acórdão seguiram o entendimento do juízo a quo em aproximadamente 83\% dos registros. 


\section{Resultados de dados cruzados de duas variáveis}

Nessa seção serão agrupadas algumas variáveis com o intuito de alcançar conclusões mais precisas do teor pesquisado e explorar correlações entre variáveis.

Tabela 14 - Setor econômico do réu X Motivo ou objeto da ação

\begin{tabular}{|c|c|c|c|c|c|c|c|c|}
\hline \multirow[b]{2}{*}{$\begin{array}{c}\text { Setor } \\
\text { econômico } \\
\text { do réu }\end{array}$} & \multicolumn{7}{|c|}{ Motivo ou objeto da ação } & \multirow[b]{2}{*}{ Total } \\
\hline & Desmatamento & Poluição & $\begin{array}{l}\text { Pesca/com. } \\
\text { ilegal }\end{array}$ & $\begin{array}{l}\text { Área não } \\
\text { edificável }\end{array}$ & $\begin{array}{c}\text { Extração } \\
\text { mineral }\end{array}$ & Licenciamento & Outros & \\
\hline Comércio & 1 & 1 & 13 & 52 & 4 & 2 & 3 & 76 \\
\hline Indústrias & 0 & 2 & 0 & 1 & 0 & 0 & 0 & 3 \\
\hline $\begin{array}{l}\text { Hotelaria - } \\
\text { imobiliário }\end{array}$ & 0 & 0 & 0 & 10 & 1 & 1 & 0 & 12 \\
\hline Pesca & 0 & 0 & 11 & 1 & 0 & 0 & 0 & 12 \\
\hline Construção & 1 & 0 & 0 & 10 & 0 & 2 & 0 & 13 \\
\hline $\begin{array}{l}\text { Serviço } \\
\text { público }\end{array}$ & 2 & 2 & 0 & 7 & 1 & 6 & 3 & 21 \\
\hline Outros & 1 & 1 & 0 & 10 & 2 & 2 & 1 & 17 \\
\hline $\begin{array}{l}\text { Informação } \\
\text { não } \\
\text { disponível }\end{array}$ & 16 & 0 & 4 & 53 & 7 & 1 & 3 & 84 \\
\hline Total & 21 & 6 & 28 & 144 & 15 & 14 & 10 & 238 \\
\hline
\end{tabular}

Tabela 15 - Setor econômico do réu X Bem ambiental protegido

\begin{tabular}{|c|c|c|c|c|c|c|c|c|c|c|}
\hline \multirow{2}{*}{$\begin{array}{c}\text { Setor econômico } \\
\text { do réu }\end{array}$} & \multicolumn{9}{|c|}{ Bem ambiental protegido } & \multirow[b]{2}{*}{ Total } \\
\hline & Dunas & $\begin{array}{c}\text { Faixa praia ou } \\
\text { terreno marinha }\end{array}$ & Mangue & Flora & Fauna & Minério & Água & Outros & $\begin{array}{l}\text { Não se } \\
\text { aplica }\end{array}$ & \\
\hline Comércio & 3 & 39 & 5 & 1 & 12 & 6 & 7 & 2 & 1 & 76 \\
\hline Indústrias & 0 & 0 & 0 & 0 & 0 & 0 & 3 & 0 & 0 & 3 \\
\hline $\begin{array}{l}\text { Hotelaria - } \\
\text { imobiliário }\end{array}$ & 4 & 3 & 1 & 0 & 1 & 1 & 1 & 1 & 0 & 12 \\
\hline Pesca & 0 & 0 & 0 & 0 & 11 & 0 & 1 & 0 & 0 & 12 \\
\hline Construção & 7 & 1 & 1 & 0 & 0 & 0 & 2 & 2 & 0 & 13 \\
\hline Serviço público & 2 & 4 & 3 & 2 & 0 & 1 & 6 & 2 & 1 & 21 \\
\hline Outros & 6 & 1 & 0 & 2 & 1 & 3 & 3 & 1 & 0 & 17 \\
\hline $\begin{array}{l}\text { Informação não } \\
\text { disponível }\end{array}$ & 9 & 3 & 22 & 5 & 5 & 7 & 27 & 6 & 0 & 84 \\
\hline Total & 31 & 51 & 32 & 10 & 30 & 18 & 50 & 14 & 2 & 238 \\
\hline
\end{tabular}

O dado mais esclarecedor desses cruzamentos está associado à ocorrência de atividades comerciais em área não edificável (APP na região litorânea). 
Pelo teor das petições iniciais, observou-se que esse fato se vincula a intensa ocupação em área de APP por "barracas" que oferecem serviços de bar e restaurante, especialmente na faixa de praia.

Além disso, o setor comercial também é responsável, com frequência, pela venda ilegal de lagosta (em período de defeso ou abaixo das dimensões permitidas) e as decorrentes da extração de areia.

A degradação de área não edificável é gerada também pelas construções e demais ações dos setores da construção civil e dos ramos de hotelaria e de serviços imobiliários. A maior presença do serviço público dentre os itens do motivo ou objeto da ação revela que o licenciamento de empreendimentos tem ocorrido com maior frequência com relação aos outros.

Tabela 16 - Município onde se situa o bem X Bem ambiental protegido

\begin{tabular}{|c|c|c|c|c|c|c|c|c|c|c|}
\hline \multirow[b]{2}{*}{$\begin{array}{l}\text { Município onde } \\
\text { se situa o bem }\end{array}$} & \multicolumn{9}{|c|}{ Bem ambiental protegido } & \multirow[b]{2}{*}{ Total } \\
\hline & Dunas & $\begin{array}{c}\text { Faixa de Praia } \\
\text { - terreno de } \\
\text { marinha }\end{array}$ & Mangue & Flora & Fauna & Minério & Água & Outros & $\begin{array}{l}\text { Não se } \\
\text { aplica }\end{array}$ & \\
\hline Fortaleza & 3 & 6 & 17 & 4 & 5 & 0 & 11 & 1 & 1 & 48 \\
\hline Aquiraz & 13 & 1 & 1 & 1 & 2 & 5 & 4 & 7 & 1 & 35 \\
\hline Caucaia & 4 & 12 & 3 & 2 & 0 & 3 & 4 & 1 & 0 & 29 \\
\hline Cascavel & 10 & 28 & 10 & 1 & 1 & 1 & 2 & 0 & 0 & 53 \\
\hline Eusébio & 0 & 1 & 1 & 0 & 0 & 0 & 5 & 0 & 0 & 7 \\
\hline Paracuru & 0 & 0 & 0 & 0 & 5 & 1 & 0 & 0 & 0 & 6 \\
\hline Canindé & 0 & 0 & 0 & 0 & 0 & 1 & 14 & 0 & 0 & 15 \\
\hline $\begin{array}{l}\text { São Gonçalo do } \\
\text { Amarante }\end{array}$ & 0 & 1 & 0 & 0 & 0 & 0 & 4 & 2 & 0 & 7 \\
\hline Outros & 1 & 2 & 0 & 2 & 1 & 7 & 6 & 1 & 0 & 20 \\
\hline $\begin{array}{l}\text {-Informação não } \\
\text { disponível }\end{array}$ & 0 & 0 & 0 & 0 & 16 & 0 & 0 & 2 & 0 & 18 \\
\hline Total & 31 & 51 & 32 & 10 & 30 & 18 & 50 & 14 & 2 & 238 \\
\hline
\end{tabular}

Essa interseção de variáveis demonstra o que já se tem relatado anteriormente. O Município de Cascavel, individualmente considerado, responde pela maior frequência de degradação ao meio ambiente $(22,3 \%)$, com incidência marcante em faixa de praia, em dunas e em área de mangue, ocasionada por edificações (principalmente barracas de praia, moradias e setor hoteleiro).

Fortaleza vem em seguida com 20,2\% do total, desta feita, concentrado mais agressões ambientais em área de mangue, decorrentes das características apresentadas pelo ecossistema do Parque do Cocó e pela proteção de margens de rios, riachos e lagoas.

Aquiraz (14,7\%) e Caucaia (12,2\%) compõem o polo dos municípios com outros registros consideráveis de degradações, semelhantemente ao modelo de Fortaleza. 
Realizado esse apanhado, convém realizar agora a conclusão do trabalho em sua totalidade mediante a integração do conteúdo estudado em cotejo com o levantamento empírico que acaba de ser relatado.

\section{Conclusão}

Com a redemocratização e o advento da Constituição Federal de 1988 o Ministério Público alcançou gradualmente um novo papel institucional. A consolidação de um conjunto de garantias ao exercício profissional associada a dispositivos legais e constitucionais que posicionaram o MP no centro do sistema de proteção dos direitos fundamentais, em particular de direitos coletivos e difusos, criaram um cenário favorável ao empoderamento desta instituição dentro do quadro político e social brasileiro.

grande destaque e relevância alcançado pelo MP exige que se estude de maneira mais profunda a atuação efetiva dos seus membros no cumprimento das suas atribuições constitucionais. Assim, procurou-se identificar e analisar no presente trabalho, por meio de pesquisa empírica, os aspectos materiais e procedimentais relacionados à busca de provimento jurisdicional mediante o manejo de ação civil pública na jurisdição Fortaleza.

A ação civil pública (petição inicial) é instruída com um Procedimento Administrativo (PA) ou Inquérito Civil (IC), cuja iniciativa é provocada em aproximadamente $92 \%$ dos casos por órgãos públicos vinculados à fiscalização (75\%) ou pela sociedade (17\%). Mesmo havendo algum tipo de convenção ou acordo entre o Parquet e os órgãos estatais sobre a remessa de peças de informações de autuações ou ocorrências de danos ambientais, estes dados reforçam a análise sobre a importância de se repensar o modelo de atuação fiscalizadora e repressiva em face das ocorrências nessa seara. Refletir sobre o planejamento das ações, mapeamento dos setores com maiores registros e sobre maximização dos instrumentos de ação que permitam expandir e valorizar a ação coordenada entre o MPF e os órgãos dotados de poder de polícia.

O perfil do réu degradador do meio ambiente nessas ações está voltado para a individualidade na composição no polo passivo por pessoas naturais e no exercício da atividade econômica comercial. As informações acerca do setor econômico sobre o qual incidem as ações mostram-se em sintonia como perfil identificado nas demais variáveis. A prevalência da violação relacionada ao segmento do comércio liga-se a ações contra indivíduos com peso financeiro e impacto ambiental relativamente menor. Setores que se imaginaria ter maior importância como a indústria ou a hotelaria, este último relacionado a alguns problemas na ocupação da área costeira, aparecem com pequena frequência.

Sobressai aí uma tendência a atuação pulverizada sobre agentes individuais e em setores específicos. Não se vislumbra uma ação mais sistemática e programada em que se busque a eficiência na alocação dos recursos investigativos e judiciais do MPF baseado em dados sobre intensidade dos danos ou amplitude da incidência. Seguindo a reboque dos fatos ou das ações dos órgãos fiscalizadores, 
o MPF acaba por não atuar baseado em dados estratégicos que permitissem a maior eficiência em sua atividade preventiva e repressiva.

A motivação do manejo de ACP é determinada principalmente pela ocupação irregular na orla litorânea dos municípios de Fortaleza, Cascavel, Aquiraz e Caucaia, em faixa de praia ou terreno de marinha, dunas, mangue; pela poluição nas margens de rios e açudes e pela pesca e comércio ilegal de lagosta. Com efeito, uma atuação sistemática baseada no conhecimento prévio dos riscos potenciais de impacto ambiental nas áreas litorânea desses municípios em conjunto com a administração local e a utilização de rotinas de fiscalização e implementação de campanhas educativas acerca da legalidade da atividade pesqueira, promovendo a conscientização de pescadores, comerciantes e consumidores, poderia ampliar a eficiência das ações e aprimorar ainda mais o papel do MPF na proteção desses bens ambientais e na gestão dos conflitos nessa área.

No tocante ao trâmite processual, identificou-se um tempo médio de decisão sobre o pedido de tutela de urgência em 222 dias, refletindo um gravame à efetividade dos princípios ambientais da precaução e da prevenção, fundamentais na proteção preventiva do meio ambiente. Ademais, foram deferidas apenas $18 \%$ das petições liminares e $72 \%$ delas sequer chegaram a ser apreciadas. A situação já é onerada pelo fato de $51 \%$ das ações não peticionarem qualquer decisão liminar, presumindo ama grande quantidade de ações cujo objeto resume-se à condenação pecuniária por dano irreversível ao meio ambiente, haja vista a impossibilidade de restaurar sua higidez.

O exercício da função jurisdicional em primeira instância consubstanciado na prolação da sentença foi realizado em 46,2\% dos casos e contou com uma duração média 21 meses. Levando-se em conta os exercícios mais antigos, tem-se que dos aforamentos iniciados em 2009 ainda não foram julgados aproximadamente $30 \%$ dos feitos, aumentando esse número para $40 \%$ em 2010 . Nessas circunstâncias, do total de demandas julgadas, o percentual de insucesso foi de $43,7 \%$, enquanto o de êxito alcançou a cifra de $57,3 \%$. No total das ações propostas, houve um registro de sucesso em praticamente um quarto $(26 \%)$.

Diante desse quadro, percebe-se que a prestação jurisdicional na tutela do meio ambiente nos moldes estudados apresenta insuficiência qualitativa e quantitativa. Sob o aspecto qualitativo destaca-se a demora na atenção às demandas urgentes submetidas à apreciação, cujo prolongamento resulta em geral na inutilidade da prestação, o que equivale a dizer, na continuidade da degradação ambiental por ato comissivo ou omissivo. Dentro de um critério de razoabilidade e de proporcionalidade, tomando por referência o conjunto das ações ainda não julgadas (54\%), que reflete o aspecto quantitativo, e o interstício para a prolação da sentença referido anteriormente, a resposta do Judiciário às questões ambientais (sempre urgentes) não atende às expectativas de uma duração razoável do processo num universo de demandas caracterizadas pela baixa complexidade (70\% de réus individuais e pessoas naturais), mesmo considerando a necessidade de produção de prova pericial na instrução de alguns feitos (exceção). Ressalte-se, contudo, que esta variável não envolve muito mais um problema na resposta judicial do que propriamente uma deficiência do MP. 
Além disso, o trânsito em julgado ainda não ocorreu em 50\%, dos casos sentenciados, pois são impugnados com recurso de apelação, dando seguimento ao trâmite dos feitos agora na segunda instância, dos quais $47 \%$ ainda não foram julgados. Esse quadro expõe um diagnóstico à administração judiciária que exige uma redefinição de suas metas e estruturas organizacionais para o atendimento prioritário aos direitos fundamentais difusos, de alcance expressivo à coletividade como um todo.

Da apreensão dessa conjuntura na seara jurisdicional pelo Ministério Público Federal e diante do papel do qual está imbuído como agente ativo na realização das finalidades constitucionais do estado brasileiro, impende repensar sua atuação institucional a partir das considerações acerca das ferramentas jurídicas que dispõe. O leque composto por instrumentos processuais e administrativos amplia a margem de discricionariedade dos membros ministeriais na condução das especificidades de cada caso para o deslinde que melhor atenda ao princípio administrativo da eficiência e aos objetivos institucionais do MP.

Em matéria ambiental, realizada a instrução do PA ou IC e constatada a ocorrência de dano, dispõe o membro do Parquet, em primeira mão, da faculdade de utilização dos instrumentos da "Recomendação", principalmente nas situações de menor complexidade técnica e jurídica, e do "Termo de Ajuste de Conduta (TAC)", este com a necessária interveniência do órgão ambiental competente, seja para auxiliar na composição de cláusulas ligadas às especificidades técnicas (não jurídicas), como também exercer o encargo de acompanhar o seu cumprimento. Este procedimento é vantajoso porque avoca o deslinde de controvérsias em matéria ambiental para o âmbito da própria instituição, contribuindo assim para mitigar o vulto de processos em trâmite no Poder Judiciário e proporcionar à sociedade a solução de casos complexos envolvendo esse bem essencial à qualidade de vida com a celeridade que os casos demandam.

Caso o requerido não atenda à respectiva Recomendação ou, mesmo firmando o TAC, não venha a cumprir os seus termos, resta em última ratio ao Procurador da República recorrer às vias judiciais. No primeiro caso (Recomendação), propõe ação civil pública, ação de conhecimento com rito ordinário e que demanda ampla ilação probatória. Mas no que tange ao segundo, constituindo o TAC uma espécie da modalidade título executivo extrajudicial, o MPF ajuizará diretamente ação de execução, vale dizer, sem a necessidade do moroso processo de conhecimento.

Essa mudança de paradigma na atuação ministerial realçaria o seu papel como um agente catalizador de construção de soluções consensuais envolvendo os múltiplos atores. A articulação dos envolvida e a produção de uma solução consensual favorece a adesão, a razoabilidade, a redução do tempo e cessação imediata das ações danosas. Com o TAC, não o problema não se exporia às indefinições do tempo de cognição, de deliberação e das intempéries dos juízos de valor de agentes externos. A subutilização dos instrumentos administrativos demonstra ainda hoje uma preferência pela clássica atuação do Ministério Público "demandista", que em maior medida transfere ao Poder Judiciário a solução das controvérsias apuradas em PA ou IC. 
Os dados e as análises permitem concluir sobre a necessidade de aprimoramento no paradigma de atuação do MPF no campo da tutela do meio ambiente. Um uso mais racional e planejado de instrumentos já existentes na legislação e um planejamento mais cuidadoso das ações com base em dados e estudos permitiriam ampliar a eficácia dos procedimentos, melhor a forma de gestão dos conflitos, reduzir o grau de judicialização e favorecer a consecução dos princípios que norteiam a proteção ao meio ambiente.

\section{Referências}

ALEXY, Robert. Teoria dos direitos fundamentais. Tradução: Virgílio Afonso da Silva. São Paulo: Malheiros, 2008.

ALMEIDA, Gregório Assagra de. O Ministério Público no neoconstitucionalismo: perfil constitucional e alguns fatores de ampliação de sua legitimação social. In: ROSENVALD, Nelson (org.). Temas atuais do Ministério Público. 4. ed. Salvador: Juspodivm, 2013.

ALMEIDA, João Batista de. Aspectos controvertidos da ação civil pública. 2. ed. São Paulo: RT, 2009.

ARANTES, Rogério Bastos. Ministério Público e política no Brasil. São Paulo: EDUC/Sumaré/Fapesp, 2002.

BASTOS, Celso Ribeiro; MARTINS, Ives Gandra. Comentários à Constituição do Brasil. São Paulo: Saraiva, 1997. v. 4. t. IV.

BECK, Ulrich. Sociedade de risco: rumo a uma outra modernidade. Tradução: Sebastião Nascimento. São Paulo: Editora 34, 2010.

BONAVIDES, Paulo. Curso de direito constitucional. 25. ed. São Paulo: Malheiros, 2010.

BONAVIDES, Paulo. Os dois Ministérios Públicos do Brasil: o da constituição e o do governo. In: MOURA JÚNIOR, Flávio Paixão de et al. (coord.). Ministério Público e a ordem social justa. Belo Horizonte: Del Rey, 2003.

BRASIL. Constituição. República Federativa do Brasil de 1988. Brasília, DF: Senado Federal, 5 out. 1988.

BRASIL. Lei Complementar n. 75, de 20 de maio de 1993. Dispõe sobre a organização, as atribuições e o estatuto do Ministério Público da União. Diário Oficial da União, Brasília, DF, 21 maio 1993. Disponível em: http://www.planalto.gov.br/ccivil_03/leis/lcp/lcp75.htm. Acesso em: 10 jul. 2014.

BRASIL. Lei n. 4.717, de 29 de junho de 1965. Regula a ação popular. Diário Oficial da União, Brasília, DF, 30 jun. 1965. Disponível em: http://www.planalto.gov.br/ccivil_03/leis/14717.htm. Acesso em: 10 jul. 2014. 
BRASIL. Lei n. 7.347, de 24 de julho de 1985. Disciplina a ação civil pública de responsabilidade por danos causados ao meio-ambiente, ao consumidor, a bens e direitos de valor artístico, estético, histórico, turístico e paisagístico e dá outras providências. Diário Oficial da União, Brasília, DF, 25 jul. 1985. Disponível em: http://www.planalto.gov.br/ccivil_03/leis/17347compilada.htm. Acesso em: 10 jul. 2014.

BRASIL. Lei n. 8.625, de 12 de fevereiro de 1993. Institui a Lei Orgânica Nacional do Ministério Público, dispõe sobre normas gerais para a organização do Ministério Público dos Estados e dá outras providências. Diário Oficial da União, Brasília, DF, 13 fev. 1993. Disponível em: http://www. planalto.gov.br/ccivil_03/leis/18625.htm. Acesso em: 10 jul. 2014.

CRETELLA JÚNIOR, José. Comentários à Constituição de 1988. 2. ed. Rio de Janeiro: Forense Universitária, 1989. v. VI.

DAMACENA, Fernanda Dalla Libera; CARVALHO, Délton Winter de. O Estado Democrático de direito ambiental e as catástrofes ambientais: evolução histórica e desafios. Pensar - Revista, v. 18, n. 2, p. 470-494, maio/ago. 2013.

DINAMARCO, Cândido Rangel. A reforma do código de processo civil. São Paulo: Malheiros, 1995.

FERRAZ, Sérgio. Responsabilidade civil por dano ecológico. Revista de Direito Público, v. 49-50, 1977.

GARCIA, Maria da Glória F. P. D. O lugar do direito na proteção do ambiente. Coimbra: Almedina, 2007.

GOULART, Marcelo Pedroso. Elementos para uma teoria geral do Ministério Público. Belo Horizonte: Arraes, 2013.

MILARÉ, Édis. Ação civil pública, instrumento indutor da sustentabilidade. In: MILARÉ, Édis (coord.). A ação civil pública após 25 anos. São Paulo: RT, 2010.

MILARÉ, Édis. Direito do ambiente - a gestão ambiental em foco. 7. ed. São Paulo: RT, 2011.

MIRRA, Álvaro Luiz Valery. Ação civil pública e reparação do dano ao meio ambiente. 2. ed. São Paulo: Juarez de Oliveira, 2004.

PEREZ LUÑO, Antonio Enrique. Derechos humanos, estado de derecho e constitución. 9. ed. Madrid: Tecnos, 2005.

SACCO, Ricardo Ferreira. Constitucionalismo e Ministério Público: uma visão panorâmica. Belo Horizonte: Mandamentos, FCH/FUMEC, 2008.

SARLET, Ingo Wolfang. A eficácia dos direitos fundamentais. 10. ed. Porto Alegre: Livraria do Advogado, 2009.

SILVA, Cátia Ainda. Justiça em jogo: novas facetas da atuação dos promotores de justiça. São Paulo: Universidade de São Paulo, 2001.

SILVA, José Afonso da. Comentário contextual à constituição. 3. ed. São Paulo: Malheiros, 2007.

VIGLIAR, José Marcelo de Menezes. Tutela jurisdicional coletiva. 3. ed. São Paulo: Atlas, 2001. 
